\title{
Analysis of Factors Causing The Delay of the Storage Tank Project Using Fault Tree Analysis
}

\author{
Abdurrohman \\ Department of Technology Management, Institut Teknologi Sepuluh Nopember, Surabaya \\ e-mail: abdurrohman089@gmail.com
}

\begin{abstract}
The Storage Tank Project is a national vital object that supports the operational reliability program of the Fuel Oil distribution. But there was a delay in the implementation of work by $31.35 \%$. This research purpose to identify the factors and indicators that cause delays in the storage tank construction project. This research method uses Fault Tree Analysis. Factors and indicators are FTA Event inputs which are then illustrated by FTA diagrams. FTA using Boolean algebra formulation results in a probability value for each Event.Objek research is in the construction Storage tanks in Surabaya. Work items in the research are Foundation work with a weight of $26.50 \%$ and Construction Work with a weight of $36.94 \%$. From the results of this research there are two indicators with the largest probability value. First, the Soil Data Report is not suitable for foundation work with a value of 0.968 in the owner's area. Therefore, the owner must be more careful in making design documents, especially on foundation work. Second, the lack of manpower with a probability value of 0.912 in construction work in the Contractor's area. in this case the contractor must ensure that the manpower has the required qualifications. Especially in Welder certification.
\end{abstract}

Keywords - Delay factor, Fault Tree Analysis, Storage Tank.

\section{INTRODUCTION}

$\mathrm{T}_{1}$ HE storage tank project has a very complex difficulty level. In addition, the completion of the project is always monitored. Delays in completion will have an impact on the fuel distribution links at the company. Therefore, in this storage tank project, it requires timeliness in its completion (Figure 1). But in fact, this timeliness expectation is highly inappropriate. This can affect other facilities that have been planned to be integrated with the storage tank and will have a very large loss.

Reviewing the project delays that have occurred, then take a sample of ongoing projects to be reviewed in terms of risk and timeliness of the project. In this research, a storage tank project in Surabaya will be reviewed as a research object. This project was built to increase fuel storage capacity.

There is a determination of the number of project delays from 2009-2011. The dominant factor in project delays is due to lack of manpower in the areas of Bali and Southeast Nusa Tenggara with a probability of $91.58 \%$. Design factor is also one of the dominant factors with a probability of $87.80 \%$. To overcome this problem, the company established a reference design for the storage tank construction project. The design includes several variable tanks, namely tanks with a capacity of 500 Kilo Liters to tanks with a capacity of 20,000 Kilo Liters. The making of this design aims to avoid time delays
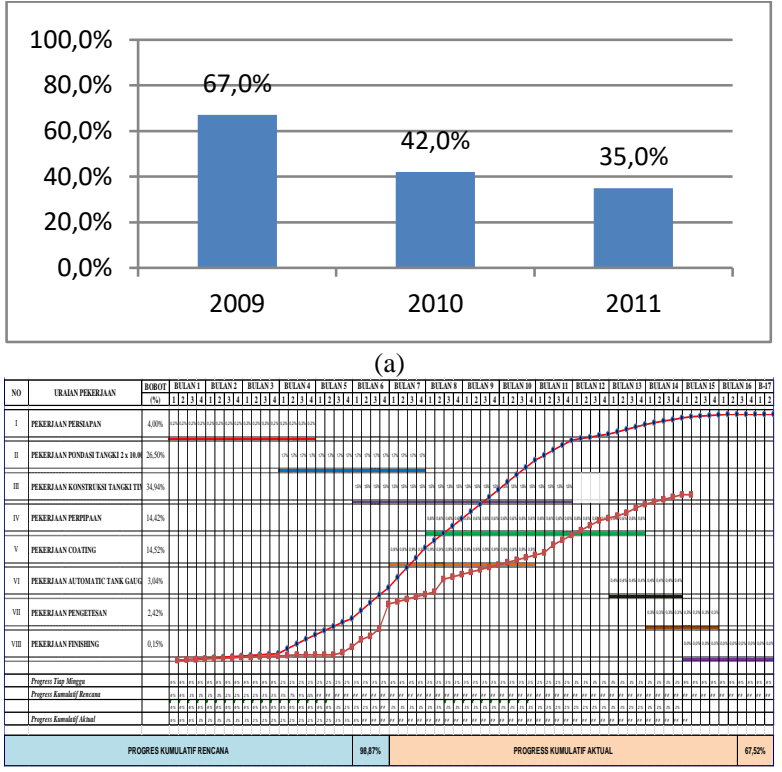

(b)

Figure 1. (a) Performance Reability \& Construction, (b) S-curve Storage Tank Project.

due to design. although the foundation design still causes some changes until the latest soil test results are released.

There is a progress deviation of $31.35 \%$ of the planned work implementation. This deviation can result in a delay in project completion. Therefore research is needed to find out the cause of the delay. This research method uses the Fault Tree Analysis method. Factors and indicators are input for FTA events which are then translated into FTA diagrams. The FTA formulation uses Boolean Algebra with the results in the form of probability values at each Event.

The purpose of this determination is to determine the causes and prevention efforts by considering the aspects of project timeliness and quality. The objectives of this study are as follows:

a) To identify the factors causing the delay in the Storage Tank construction project.

b) Making efforts to prevent the risk of delays in completing the Storage Tank project.

\section{LITERATURE REVIEW}

Construction projects in the oil and gas sector generally aim to increase supply and replace existing facilities [7]. the storage tank project has stages of work. preparation of foundation, tank errection work, testing, but this construction 


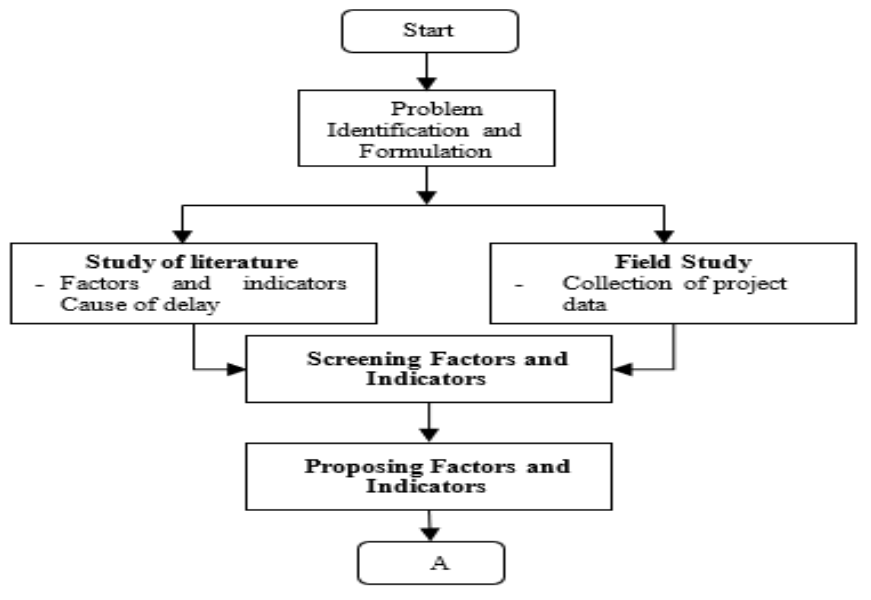

(a)

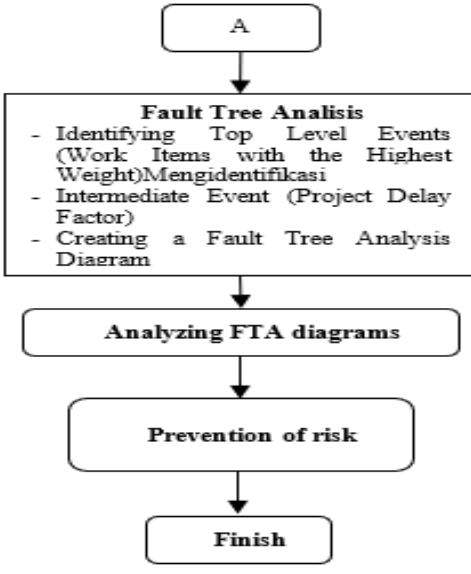

(b)

Figure 2. Diagram of The Work Item to be Analyzed: (a) Methodology of the preparation phase, (b) Methodology analysis phase.

Table 1.

The results of the literature study in previous studies are the factors causing delays in construction projects

\begin{tabular}{|c|c|c|}
\hline No & Previous research references & Cause of Delay \\
\hline 1 & $\begin{array}{l}\text { Salama et al, } 2008 \text {; Marzouk dan El Rasas, } 2013 \text {; Sambasivan dan Soon, } 2007 \text {; Odeh dan Battaineh, } 2002 \text {; } \\
\text { Kaming et al, } 1997\end{array}$ & Man Power \\
\hline 2 & Salama et al, 2008; Fallahnejad, 2013 ; Ruqaishi dan Bashir, 2013; Frimpong et al, 2003; Kaming et al, 1997 & Materials \\
\hline 3 & $\begin{array}{l}\text { Salama et al, } 2008 \text {; Marzouk dan El Rasas, } 2013 \text {; Sambasivan dan Soon, } 2007 \text {; Odeh dan Battaineh, } 2002 \text {; } \\
\text { Kaming et al, } 1997\end{array}$ & Machine \\
\hline 4 & $\begin{array}{l}\text { Ruqaishi dan Bashir, } 2013 \text {; Sambasivan dan Soon, } 2007 \text {; Odeh dan Battaineh, 2002, Orangi et al, } 2011 \text { dan } \\
\text { Kaming et al, 1997; Sweis et al, 2008; Fallahnejad, 2013; Doloi et al, } 2012\end{array}$ & External \\
\hline 5 & $\begin{array}{l}\text { Ruqaishi dan Bashir, } 2013 \text {; Orangi et al, } 2011 \text {; Doloi et al, } 2012 \text {; Marzouk dan El Rasas, } 2013 \text {; Sambasivan dan } \\
\text { Soon, } 2007 \text {; Odeh dan Battaineh, } 2002 \text {; Kaming et al, 1997; Toor dan Ogunlana, 2008; Alaghbari et al, } 2007\end{array}$ & Project Related \\
\hline 6 & $\begin{array}{l}\text { Assaf dan Al Heiji 2006; Sambasivan dan Soon, 2008; Marzouk dan El Rasas, 2013; Doloi et al, 2012; Sweis et al } \\
\text { 2008; Fallahnejad, } 2013\end{array}$ & Contract \\
\hline 7 & $\begin{array}{l}\text { Sambasivan dan Soon, } 2007 \text {; Ruqaishi dan Bashir, } 2013 \text {; Orangi et al, 2011; Alaghbari et al, } 2007 \text {; Le-Hoai et } \\
\text { al, } 2008\end{array}$ & Site Related \\
\hline 8 & $\begin{array}{l}\text { Ruqaishi dan Bashir, } 2013 \text {; Sambasivan dan Soon, } 2007 \text {; Orangi et al, } 2011 \text {; dan Doloi et al, 2012; Odeh dan } \\
\text { Battaineh, } 2002 \text {; Alaghbari et al, } 2007\end{array}$ & Communication \\
\hline 9 & Sweis et al, 2008 ; Frimpong et al, 2003 ; Alaghbari et al, 2007; Fallahnejad, 2013 & Finance \\
\hline 10 & Orangi et al, 2011 ; Kaming et al, 1997 ; Toor dan Ogunlana, 2008 & Design \\
\hline
\end{tabular}

work is more dominant to mechanical work. In pipeline construction works, a number of typical jobs with construction works in which the sequence is in the form of pipeline deployment, joint welding, testing, similar to embankment tank work, this work is dominated by mechanical work. Whereas in the metering \& custody system construction work and the dominant pumping system to mechanical work and equipment package. Unlike the case with dock construction work, in this work the dominance of civil and mechanical works is proportional. Reviewing the characteristics of construction work in typical oil and gas facilities with general construction, in this study the characteristics can be approached with the same approach as in general construction projects.

Delay in a project is a thing that often occurs in a project implementation, the cause can be sourced from various elements in the project and other elements outside the project. The characteristics of each project will produce different causal factors. Through previous studies on construction projects that were late found several dominant factors, these factors are explained in Table 1.

\section{RESEARCH METHODOLOGY}

The delay analysis method in the storage tank project use the Fault Tree Analysis (FTA) method. use the identification of indicators that cause delays. Then it is used as a means to determine the main source of project delays. Event data input on this FTA Diagram uses indicators that have been included in each delay factor. The formulation in the FTA diagram uses Boolean Algebra. The flow of this research will be explained by flowchart in Figure 2.

In determining the factors of delay, we need a tool that can analyze these factors. In this study can use the Fault tree Analysis (FTA). In the FTA there are stages that will be discussed in the points below.

a. Identifying the Top Level Event (Items with the highest weight). This event is a work item with the highest weight is foundation work and steel construction.

b. Identifying an Intermediate Event. This item is a factor that causes delays in work. This item obtained in the literature about the factors that influence the delay. This factor is then used as an Intermediate Event.

c. Indicator Screaning (Determining Basic Events). The purpose of this screaning is to select indicators that are relevant to the storage tank construction project. These indicators become intermediate input events under each factor.

d. Creating a Fault Tree Analysis Diagram An FTA design 
Table 2.

FTA diagram code for foundation Work

\begin{tabular}{|c|c|c|c|}
\hline$\overline{\mathrm{COODE}}$ & EVENT & CODE & EVENT \\
\hline A 1 & Owner & B5 1 & Repeated Design Changes \\
\hline A 2 & Contractor & C 1 & Changes in Material Specifications During Construction \\
\hline A 3 & External & $\mathrm{C} 2$ & Work restrictions in the field \\
\hline B1 1 & Materials & C 3 & Utilities such as water and electricity are not available on site \\
\hline B1 2 & Project Related & $\mathrm{C} 4$ & Delay in producing design documents \\
\hline B1 3 & Site Related & $\mathrm{C} 5$ & Inappropriate and unclear design drawings \\
\hline B1 4 & Communication & $\mathrm{C} 6$ & No use of sophisticated software in making designs \\
\hline B1 5 & Finance & $\mathrm{C} 7$ & Incomplete data collection and inadequate survey before design \\
\hline B1 6 & Manpower & $\mathrm{C} 8$ & Their dismissal of the work by the project owner \\
\hline B1 7 & Materials & $\mathrm{C} 9$ & long decision making \\
\hline B1 8 & Machine & $\mathrm{C} 10$ & delays in the payment process \\
\hline B19 & Finance & C 11 & lack of experienced workforce in the project organization \\
\hline B1 10 & Site Related & $\mathrm{C} 12$ & Workers who are less qualified work on the project \\
\hline B1 11 & External & $\mathrm{C} 13$ & Low Manpower Productivity \\
\hline B1 12 & Communication & $\mathrm{C} 14$ & Limitations on the amount of material on the market \\
\hline B2 1 & Lack of effective supervision of the project & C 15 & Late submission of samples / samples of material \\
\hline B2 2 & non-renewable soil data & C 16 & Fluctuations in material prices \\
\hline B23 & Lack of Manpower Availability & $\mathrm{C} 17$ & Low quality of material \\
\hline B2 4 & Lack of Material & C 18 & Limitations on the Amount of Work Equipment \\
\hline B2 5 & Poor project cash management & C 19 & Damaged working equipment condition \\
\hline B3 1 & Design & $\mathrm{C} 20$ & Difficulties Project financing by the contractor \\
\hline B3 2 & Delay in materials delivery & $\mathrm{C} 21$ & Safety regulations that are not complied with by the contractor \\
\hline B4 1 & Complexity of design & $\mathrm{C} 22$ & Unsupportive weather conditions \\
\hline B4 2 & Less Experience Design Team & C 23 & difficulty in coordination between Stakeholder \\
\hline
\end{tabular}

Table 3.

FTA diagram code for steel construction

\begin{tabular}{|c|c|c|c|}
\hline$\overline{\mathrm{CODE}}$ & EVENT & CODE & EVENT \\
\hline A 1 & Owner & B2 7 & Inappropriate project planning \\
\hline A 2 & Contractor & B2 8 & Poor project cash management by the contractor \\
\hline A 3 & External & B3 1 & Low Manpower productivity \\
\hline B1 1 & Materials & C 1 & Changes in material specifications during construction \\
\hline B1 2 & Project Related & $\mathrm{C} 2$ & Stops their work by the project owner \\
\hline B1 3 & Contract & C 3 & Lack of effective supervision of the project \\
\hline B1 4 & Communication & $\mathrm{C} 4$ & Project awarding with the lowest bidding method \\
\hline B1 5 & Finance & C 5 & Long decision-making \\
\hline B1 6 & Manpower & C 6 & Delay in the payment process \\
\hline B1 7 & Materials & $\mathrm{C} 7$ & Unqualified workers are employed on the project \\
\hline B1 8 & Project Related & $\mathrm{C} 8$ & Lack of manpower experienced in contracting organization \\
\hline B19 & Site Related & C 9 & Limitations on the amount of material on the market \\
\hline B1 10 & Finance & C 10 & Delay in starting long-lead material orders \\
\hline B1 11 & External & C 11 & Problems with subcontractors \\
\hline B2 1 & Work restrictions in the field & C 12 & Work accident during construction \\
\hline B2 2 & excessive bureaucratic process & C 13 & Rework caused by a contractor's mistake \\
\hline B2 3 & Lack of Manpower availability & C 14 & Safety regulations that are not complied with by the contractor \\
\hline B2 4 & material deficiencies & C 15 & difficulty in project payments by the contractor \\
\hline B2 5 & delays in material delivery & C 16 & unfavorable weather conditions \\
\hline B2 6 & $\begin{array}{l}\text { lack of experience with the project by the } \\
\text { contractor }\end{array}$ & & \\
\hline
\end{tabular}

can be made after determining the top event, intermediate event and basic event. use deductive logic to arrange the order in the diagram.

e. Analyzing Fault Tree Analysis The results of the above design use boolean algebraic formulations. Basic event probability values are obtained from the results of questionnaire analysis using deductive frequencies.

\section{DIAGRAM FAUL TREE ANALISYS}

The design of the FTA diagram is the initial stage in fault tree analysis. In its design, deductive logic is needed. Logic is needed in determining the flow of problems to the basic event. In this study, there are two diagrams, which are FTA diagrams for foundation work and FTA diagrams for Steel Construction. Foundation work has several types of secondary work in it. As a start to show work performance, the contractor should show positive progress towards the owner. This is important because it can affect future work. In addition, the contractor must ensure that the work is not only timely. The contractor must ensure that the work must be of the right quality as required by the work directors. Construction work is the main building work of a storage tank project. Construction work is the largest infestation in the embankment tank construction project. The price of each material used experiences price fluctuations so quickly. Therefore, many implementers working on storage tanks carry out material infestations at the beginning with a fantastic value that even exceeds the initial down payment.

Figure 2 shown a diagram of the work item to be analyzed. an explanation of the code in the Figure 2 will be explained in Table 2 and Table 3. 
Table 4.

Basic event probability values for foundation work

\begin{tabular}{|c|c|c|c|c|c|}
\hline CODE & BASIC EVENT & VALUE & CODE & BASIC EVENT & VALUE \\
\hline C 1 & $\begin{array}{l}\text { Changes in Material Specifications During } \\
\text { Construction }\end{array}$ & 0,595 & C 13 & Low Manpower Productivity & 0,784 \\
\hline $\mathrm{C} 2$ & Work restrictions in the field & 0,676 & C 14 & $\begin{array}{l}\text { Limitations on the amount of material } \\
\text { on the market }\end{array}$ & 0,459 \\
\hline C 3 & $\begin{array}{l}\text { Utilities such as water and electricity are not } \\
\text { available on site }\end{array}$ & 0,459 & C 15 & $\begin{array}{l}\text { Late submission of samples / samples } \\
\text { of material }\end{array}$ & 0,622 \\
\hline $\mathrm{C} 4$ & Delay in producing design documents & 0,784 & C 16 & Fluctuations in material prices & 0,459 \\
\hline C 5 & Inappropriate and unclear design drawings & 0,676 & C 17 & Low quality of material & 0,432 \\
\hline C 6 & No use of sophisticated software in making designs & 0,541 & C 18 & $\begin{array}{l}\text { Limitations on the Amount of Work } \\
\text { Equipment }\end{array}$ & 0,703 \\
\hline C 7 & $\begin{array}{l}\text { Incomplete data collection and inadequate survey } \\
\text { before design }\end{array}$ & 0,838 & C 19 & $\begin{array}{l}\text { Damaged working equipment } \\
\text { condition }\end{array}$ & 0,568 \\
\hline $\mathrm{C} 8$ & Their dismissal of the work by the project owner & 0,649 & C 20 & $\begin{array}{l}\text { Difficulties Project financing by the } \\
\text { contractor }\end{array}$ & 0,676 \\
\hline $\mathrm{C} 9$ & long decision making & 0,730 & $\mathrm{C} 21$ & $\begin{array}{l}\text { Safety regulations that are not } \\
\text { complied with by the contractor }\end{array}$ & 0,730 \\
\hline C 10 & delays in the payment process & 0,405 & $\mathrm{C} 22$ & Unsupportive weather conditions & 0,703 \\
\hline C 11 & $\begin{array}{l}\text { lack of experienced workforce in the project } \\
\text { organization }\end{array}$ & 0,757 & C 23 & $\begin{array}{l}\text { difficulty in coordination between } \\
\text { Stakeholder }\end{array}$ & 0,649 \\
\hline $\mathrm{C} 12$ & Workers who are less qualified work on the project & 0,703 & & & \\
\hline
\end{tabular}

Table 5 .

Basic event probability values for Steel Construction

\begin{tabular}{|c|c|c|c|c|c|}
\hline CODE & BASIC EVENT & VALUE & CODE & BASIC EVENT & VALUE \\
\hline C 1 & $\begin{array}{l}\text { Changes in material specifications during } \\
\text { construction }\end{array}$ & 0,541 & C 9 & $\begin{array}{l}\text { Limitations on the amount of material } \\
\text { on the market }\end{array}$ & 0,595 \\
\hline $\mathrm{C} 2$ & Stops their work by the project owner & 0,757 & C 10 & $\begin{array}{l}\text { Delay in starting long-lead material } \\
\text { orders }\end{array}$ & 0,811 \\
\hline C 3 & Lack of effective supervision of the project & 0,541 & C 11 & Problems with subcontractors & 0,595 \\
\hline $\mathrm{C} 4$ & Project awarding with the lowest bidding method & 0,541 & C 12 & Work accident during construction & 0,432 \\
\hline C 5 & Long decision-making & 0,649 & C 13 & $\begin{array}{l}\text { Rework caused by a contractor's } \\
\text { mistake }\end{array}$ & 0,676 \\
\hline $\mathrm{C} 6$ & Delay in the payment process & 0,432 & C 14 & $\begin{array}{l}\text { Safety regulations that are not } \\
\text { complied with by the contractor }\end{array}$ & 0,730 \\
\hline $\mathrm{C} 7$ & Unqualified workers are employed on the project & 0,703 & C 15 & $\begin{array}{l}\text { difficulty in project payments by the } \\
\text { contractor }\end{array}$ & 0,676 \\
\hline $\mathrm{C} 8$ & $\begin{array}{l}\text { Lack of manpower experienced in contracting } \\
\text { organization }\end{array}$ & 0,703 & C 16 & unfavorable weather conditions & 0,649 \\
\hline
\end{tabular}

Table 6.

Intermadiate event probability values for Foundation Work

\begin{tabular}{llcc}
\hline \hline CODE & \multicolumn{1}{c}{ INTERMEDIATE EVENT } & VALUE & MAPING \\
\hline B2 1 & Lack of effective supervision of the project & 0,676 & 0,968 \\
B2 2 & non-renewable soil data & 0,927 & Owner \\
B2 3 & Lack of Manpower Availability & 0,889 & Owner \\
B2 4 & Lack of Material & 0,676 & Contractor \\
B2 5 & Poor project cash management & Contractor & 0 r \\
\hline \hline
\end{tabular}

\section{IMPLEMENTASI OF FTA IN CASE STUDY}

To analyze a diagram, we need the probability value of each event on the FTA diagram. This probability value then becomes the author's reference in determining the effect of the event on project delays.

\section{A. Basic Event Probability Values}

The basic event probability value is the basis in the FTA analysis. This value is obtained from the results of the questionnaire analysis using deductive frequency. Probability values are shown in Table 4 and Table 5.

Thus, the value of the probability at each basic event. Then the intermediate event probability value will be analyzed. The highest basic event probability value for foundation work is the Incomplete data collection and inadequate survey before design with a value of 0.838 . Whereas for steel construction work is Delay in starting long-lead material orders with a value of 0.811

\section{B. Value Probability Intermediate Event}

The probability value of the basic event is the value that will be used as a discussion for the FTA results. Because the top event of the FTA is a factor that causes delays. The intermediate event probability values are shown in Table 6 and Table 7 .

The highest intermediate event probability value in foundation work is non-renewable soil data with a value of 0.968. Whereas for steel construction work is Lack of Manpower availability. With these results it can be concluded that the factors causing project delays in foundation work are design factors. Whereas for steel construction work is a manpower factor. 
Table 7.

Intermediate event probability values for Steel Construction

\begin{tabular}{|c|c|c|c|}
\hline CODE & INTERMEDIATE EVENT & VALUE & FACTORS \\
\hline B2 1 & Work restrictions in the field & 0,757 & Owner \\
\hline B2 2 & Excessive bureaucratic process & 0,649 & Owner \\
\hline B2 3 & Lack of Manpower availability & 0,912 & Contractor \\
\hline B2 4 & Material deficiencies & 0,595 & Contractor \\
\hline B2 5 & Delays in material delivery & 0,810 & Contractor \\
\hline B2 6 & lack of experience with the project by the contractor & 0,769 & Contractor \\
\hline B2 7 & Inappropriate project planning & 0,676 & Contractor \\
\hline B2 8 & Poor project cash management by the contractor & 0,676 & Contractor \\
\hline
\end{tabular}

\section{DISCUSSION}

Design is the dominant factor in causing delays. Typical research by [1-3]. The study explained that there were many changes in the design, especially standardization in the design. Unpredictable change is a high risk. In Ardiansyah's research, 2014 explained that the probability of risk occurrence in the design was $87.80 \%$. Although in his research, the design factor is not a factor with the highest probability value.

Based on this research and previous research, the Owner must pay more attention to the accuracy of the design. In mitigating the risk of design errors, the appointment of a consultant planner is the right solution. According to the Managerial Owner that the appointment of a planning consultant can make it easier to produce designs. According to the owner, the greatest difficulty is found in the design of the foundation. This is due to the unpredictable nature of the soil. Even though the land investigation has been carried out, changes are still being made to the works. It's just that the risks of these changes are different.

Lack of supply, productivity, competence, and experience from manpower are factors that often arise in every project. Research conducted by [3-7] on the delay factor of a project, found similarities in the causes of project delay. Even so, the manpower factor is indeed the most difficult thing to mitigate at any construction service provider.

Unique and temporary projects make it difficult for contractors to mitigate the risks of lack of manpower. Contractors prefer workers with temporary contracts over contracts as permanent employees. the frequent change of employees or contract workers while making the competence of each worker not maintained and monitored. Operational needs are often the reason for not recruiting manpower with permanent contracts. Workers, especially welder with valid certification, are very difficult to obtain. Welder certification has a short validity period. in addition to the non-validity of the certification period, the welder who is registered must continue to take the WPQT (Welder Performance Qualification Test) to get welding certification.

\section{CONCLUSION}

From the results of the Fault Tree Analysis, it can be analyzed factors and indicators that can be the cause of delays in the completion of a project. Factors and indicators are as follows: (1) The indicator with the highest probability value on foundation work is Event B2 2 Incorrect Soil Data Reports (Soil Data Reports that are incompatible with the depth of piling) with a value of 0.968 ; (2) The indicator with the highest probability value on Construction work is Event B2 3 Lack of manpower availability (Especially workers with welder certification) with a value of 0.912 .

To reduce the probability of risk occurring above, some prevention efforts are carried out so that it does not occur in similar projects. Prevention efforts are as follows: (1) For foundation work the owner can appoint a third party or planning consultant. The purpose of this appointment is to minimize the risk of design changes while working on the project. In addition, the owner can evaluate and select a contractor with EPC (Engineering, Procurement, Construction) qualifications during pre-tender. With these qualifications, it is expected that the contractor can reengineer the Bill of quantity that has been issued by the owner; (2) For steel construction, the contractor should have his own barn in accordance with his qualifications. So the quality of the manpower can be monitored. If the manpower recruited is freelance, it is too time-consuming and costly and quality is not monitored. This is a concern for the owner so that he can add the requirements to the pre-tender with a manpower ownership letter of support with the required qualifications.

Suggestions for further research: (1) The Fault Tree Analysis method is very suitable for analyzing the Delay Factors and Indicators. From the FTA diagram, we can look for sources of problems that occur in the project; (2) This method is very subjective according to the wishes of the researcher. Top Event segmentation can be adjusted according to the desired segmentation of researchers; (3) The character of the project is unique and temporary; factors and indicators can be different and adjusted for each project.

\section{REFERENCES}

[1] Orangi, A., Palaneeswaran, E., Wilson, J. (2011), "Exploring Delays in Victoria-Based Australian Pipeline Projects", Procedia engineering, Vol. 14, hal. 874-881.

[2] Toor, S dan Ogunlana., S.O. (2008). "Problems causing delay in major construction projects in Thailand", Journal of Construction Management and Economics, Vol. 26, hal. $394-408$.

[3] Kaming, P.F., Olomolaiye, P.O., Holt, G.D., Harris, F.C. (1997). "Factors influencing construction time and cost overruns on high-rise projects in Indonesia". Journal of Construction Management and Economics, Vol. 15, hal. $83-94$. 
The $6^{\text {th }}$ International Seminar on Science and Technology (ISST) 2020

July $25^{\text {th }} 2020$, Institut Teknologi Sepuluh Nopember, Surabaya, Indonesia

[4] Odeh, M.A. dan Battaineh, H.T. (2002), "Causes of construction delay: traditional contract.", International Journal of Project Management, Vol. 20, hal. 67-73.

[5] Marzouk, M.M. dan El Rasas, T. (2013), "Analysing Delay Causes in Egyptian Construction Projects", Journal of Advanced Research, Structural Engineering Department, Cairo University.

[6] Sambasivan, M. dan Soon, Y.W. (2007), "Causes and Effects of Delays in Malaysian Construction Industry", International Journal of Project Management. Vol. 25, hal. 517-526.

[7] Salama, M., El-Hamid, M.A., Keogh, B. (2008), "Investigating the causesof delay within oil and gas projects in the U.A.E.", Procs 24th Annual ARCOM Conference, hal. $819-827$.

[8] Assaf, S.A. dan Al Heiji, S. (2006), "Causes of Delay in Large Construction Projects", International Journal of Project Management, Vol. 24, hal. 349-357.

[9] Doloi, H., Sawhney, A., Iyer, K.C., Rentala, S. (2012), "Analysing factors affecting delays in Indian construction projects", International Journal of Project Management, Vol. 30, hal. 479-489.
[10] Fallahnejad, M.H. (2013), "Delay causes in Iran gas pipeline projects", International Journal of Project Management, Vol. 31, hal. 136-146.

[11] Frimpong, Y., Oluwoye, J., Crawford, L. (2003), "Causes of delay and cost overruns in construction of groundwater projects in a developing countries : Ghana as a case study", International Journal of Project Management, Vol. 21, hal. 321-326.

[12] Hamzah, N., Khoiry, M.A., Arshad, I., Tawil, N.M., Ani, C.A.I (2011), "Cause of Construction Delay - Theoretical Framework", Procedia Engineering, Vol. 20, hal. $490-495$.

[13] PMI (Project Management Institute, Inc). (2004), A Guide to the Project Management Body of Knowledge (PMBOK), 3rd edition, Newton Square, Pennsylvania, USA.

[14] Ruqaishi, M. dan Bashir, A.H. (2013), "Causes of Delay in Construction Projects in the Oil and Gas Industry in the Gulf', Journal of Construction Engineering Management - ASCE.

[15] Sweis, G., Sweis, R., Hammad, A.A., Shboul, A. (2008), "Delays in Construction Projects: The Case of Jordan", International Journal of Project Management. Vol. 26, hal. 665-674. 